\title{
Article
}

\section{Development of Gelatine-based Bio-film from Chicken Feet Incorporated with Sugarcane Bagasse}

Tew, S.T., Soon, Jan Mei, Benjakul, S, Prodran, T, Vittayanont, M and Tongnuanchan, P

Available at http://clok.uclan.ac.uk/17178/

Tew, S.T., Soon, Jan Mei ORCID: 0000-0003-0488-1434, Benjakul, S, Prodran, T, Vittayanont, M and Tongnuanchan, P (2017) Development of Gelatine-based Bio-film from Chicken Feet Incorporated with Sugarcane Bagasse. Nutrition and Food Science, 47 (2). ISSN 0034-6659

It is advisable to refer to the publisher's version if you intend to cite from the work. http://dx.doi.org/10.1108/NFS-07-2016-0086

For more information about UCLan's research in this area go to http://www.uclan.ac.uk/researchgroups/ and search for <name of research Group>.

For information about Research generally at UCLan please go to http://www.uclan.ac.uk/research/

All outputs in CLoK are protected by Intellectual Property Rights law, including Copyright law. Copyright, IPR and Moral Rights for the works on this site are retained by the individual authors and/or other copyright owners. Terms and conditions for use of this material are defined in the policies page.

\section{CLoK}

Central Lancashire online Knowledge www.clok.uclan.ac.uk

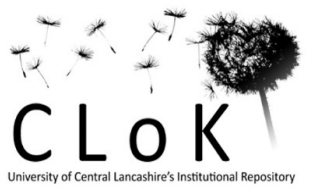




\section{emeraldinsight}

\section{Nutrition \& Food Science}

Development of gelatine-based bio-film from chicken feet incorporated with sugarcane bagasse

Sue Teng Tew Jan Mei Soon Soottawat Benjakul Thummanoon Prodran Manee Vittayanont Phakawat Tongnuanchan

\section{Article information:}

To cite this document:

Sue Teng Tew Jan Mei Soon Soottawat Benjakul Thummanoon Prodran Manee Vittayanont Phakawat Tongnuanchan , (2017)," Development of gelatine-based bio-film from chicken feet incorporated with sugarcane bagasse ", Nutrition \& Food Science, Vol. 47 Iss 2 pp. -

Permanent link to this document:

http://dx.doi.org/10.1108/NFS-07-2016-0086

Downloaded on: 26 February 2017, At: 11:37 (PT)

References: this document contains references to 0 other documents.

To copy this document: permissions@emeraldinsight.com

The fulltext of this document has been downloaded 15 times since $2017^{*}$

Access to this document was granted through an Emerald subscription provided by emerald-srm: 405310 []

\section{For Authors}

If you would like to write for this, or any other Emerald publication, then please use our Emerald for Authors service information about how to choose which publication to write for and submission guidelines are available for all. Please visit www. emeraldinsight. com/authors for more information.

\section{About Emerald www.emeraldinsight.com}

Emerald is a global publisher linking research and practice to the benefit of society. The company manages a portfolio of more than 290 journals and over 2,350 books and book series volumes, as well as providing an extensive range of online products and additional customer resources and services.

Emerald is both COUNTER 4 and TRANSFER compliant. The organization is a partner of the Committee on Publication Ethics (COPE) and also works with Portico and the LOCKSS initiative for digital archive preservation.

*Related content and download information correct at time of download. 


\section{Development of gelatine-based bio-film from chicken feet incorporated with sugarcane bagasse}

\section{Introduction}

Plastics are used worldwide in everyday lives and in different forms such as food packaging, spoons, bottles, pens, shopping plastic bags, chairs and containers.

Recycling rates for most plastic packaging are low although recyclable packaging materials has increased (Hopewell et al., 2009). Plastics take a long period of time for complete degradation as they do not degrade naturally to a large degree when released into the environment due to the many polymers that are exceptionally stable and durable (Webb et al., 2012). In order to substitute these plastics, biodegradable plastics have been developed with the same function that are comparable to traditional petrochemical-based plastics for packaging applications (Song et al., 2009). Biodegradable plastics are plastics in which the degradation mechanism is characterized by the full breakdown of the organic chemical compound by micro-organisms into water, carbon dioxide, methane, biomass and inorganic compounds under aerobic or anaerobic conditions and the action of living organisms (Deconinck and Wilde, 2013). The objectives in the development of biodegradable plastics are to utilize renewable and sustainable sources of raw materials by using crops instead of crude oil and to approach integrated waste management to reduce landfill (Davis and Song, 2006).

In the case of food packaging, edible film from natural polymer is important as an alternative to replace synthetic polymer as it can help to enhance food quality by acting as moisture, gas, aroma and lipid barriers as well as acting as a protection to a food product after the primary package is opened (Rattaya et al., 2009). Generally, edible films are thin, continuous layer of edible material which is renewable such as proteins, lipids and carbohydrates (Jongjareonrak et al., 2006). Examples of edible protein films had been developed from whey (Ramos et al., 2012, 2013), soy (Otoni et al., 2016) and sesame (Sharma and Singh, 2016), gelatin films from skin of cuttlefish (Jridi et al., 2013) and fish (Kaewruang et al., 2013; Nikoo et al., 2014; Weng et al., 2014) while other materials focused on polysaccharides such as carrageenan (Soni et al., 2016), cassava starch (Bergo et al., 2008) and methylcellulose (Rubilar et al., 2015). 
Although protein-based films have good gas barrier characteristics compared to synthetic films, they have poor mechanical properties and high water vapor permeability which are the main drawbacks of protein films acting as a packaging material (Hoque $e t$ al., 2011). Moreover, the main sources of commercial gelatin production are from skin and bones of swine and cattle but the usage of swine skin and bone is considered haram (unlawful) for Muslim and Judaism and beef gelatin is only acceptable if prepared according to religious requirements (Badii and Howell, 2006). There is also risk of contamination with bovine spongiform encephalopathy (BSE) if infected cattle skin and bones were used (Grommuang et al., 2006). Properties of fish gelatine from skins of Nile Tilapia Oreochromis niloticus) and channel catfish (Ictalurus punctatus) (Zhang et al., 2016), tilapia (Tilapia zillii) scales (Weng et al., 2014), unicorn leatherjacket (Aluterus monoceros) (Kaewruang et al., 2013) and Amur sturgeon (Acipenser schrenckii) (Nikoo et al., 2014) had been carried out as the demand for non-mammalian gelatine increases. Fish gelatine is acceptable for Islam but persisting residual odour in fish gelatin can cause problems if the film is intended for use in mildly flavoured products (Rafieian et al., 2015; Sae-Leaw and Benjakul, 2015). Chicken by-products such as chicken deboner residue (CDR) (Rafieian et al., 2015), chicken feet to replace cowhides for jokpyun (traditional Korean gel-type food) (Jun et al., 2000), chicken bones (Lim et al., 2010), chicken skin (Sarbon et al., 2013)

Sugarcane bagasse is available abundantly in sugar production and beverage industry and 1 tonne of sugarcane produces $280 \mathrm{~kg}$ of bagasse (Cerqueira et al., 2007). Although once considered a low value agricultural residue, sugarcane bagasse can be potentially utilized for its cellulose which contributes to stiffness (Afra et al., 2013), reinforcing potential (Abraham et al., 2011) and biodegradability (Chen et al., 2011). Sugarcane produces maximum surplus residue (Hiloidhari et al., 2014) and provides 40$50 \%$ cellulose content (Sun et al., 2004). To our knowledge, this is the first study that incorporates hydrolyzed sugarcane bagasse to study the potential mechanical benefits in protein based bio-film. The aim of this work was to analyse the effect of hydrolyzed sugarcane bagasse incorporation on mechanical and water vapor barrier properties of biofilm derived from chicken feet extract to utilize agricultural by-products as potential food packaging materials. 


\section{Materials and methods}

65 Chemicals

Phosphoric acid and hydrogen peroxide were purchased from Fisher Scientific (Loughborough, UK) while sodium hydroxide and sulfuric acid were purchased from RCI Labscan Limited (Bangkok, Thailand) and glycerol from Quality Reagent Chemical $\left(\mathrm{QReC}^{\mathrm{TM}}\right)$ (New Zealand). All chemicals were of analytical grade.

\section{Purification of cellulose from $S C B$}

Purification of cellulose from SCB was carried out as described by Teixeira et al. (2011) with slight modification. Oven dried SCB was blended to pass through 40 mesh screen. Five grams of dried SCB was then digested with $6 \% \mathrm{NaOH}$ solution for 4 hours in $60^{\circ} \mathrm{C}$ 
water bath. It was then stirred with magnetic stirrer while $100 \mathrm{~mL}$ hydrogen peroxide solution $(11 \% \mathrm{v} / \mathrm{v})$ was added slowly to the flask and stirred vigorously for 90 mins. The $\mathrm{SCB}$ was filtered and washed with distilled water until neutral $\mathrm{pH}$.

\section{Preparation of hydrolyzed SCB}

Hydrolyzed SCB was prepared according to Teixeira et al. (2011) with slight modification. SCB was dispersed in $100 \mathrm{~mL}$ of $6 \mathrm{M} \mathrm{H}_{2} \mathrm{SO}_{4}$ at $50^{\circ} \mathrm{C}$. It was stirred vigorously for $2 \mathrm{hrs} 500 \mathrm{ml}$ cold distilled water $\left(4^{\circ} \mathrm{C}\right)$ was added to stop the reaction. The $\mathrm{pH}$ of the solution was adjusted to $\mathrm{pH} 6-7$ through dialysis in tap water with cellulose membrane before storing the suspension in refrigerator. Moisture content of the hydrolyzed SCB suspension was carried out in triplicates (AOAC, 2000).

\section{Preparation of gelatine film with different percentage of glycerol}

Film forming solution (FFS) was prepared as described by Tongnuanchan et al. (2012, 2013) Gelatine powder was mixed with distilled water to obtain the protein concentration of $3.5 \%(\mathrm{w} / \mathrm{v})$. The mixture was heated at $70^{\circ} \mathrm{C}$ until completely dissolved. . Glycerol which acts as plasticizer was added at concentrations of $25 \%$ and $35 \%(\mathrm{w} / \mathrm{w})$ of protein content. The film was then prepared by casting $4.0 \mathrm{~g}$ FFS onto a rimmed silicone resin plate $\left(50 \times 50 \mathrm{~mm}^{2}\right)$ and air-blown for $12 \mathrm{hrs}$ at $25^{\circ} \mathrm{C}$. The film was further dried at $25^{\circ} \mathrm{C}$ and $50 \pm 5 \%$ relative humidity for $24 \mathrm{~h}$ in an environmental chamber (WTB Binder, Tuttlingen, Germany) (Prodpran et al., 2007). The resulting films were peeled off manually and subjected to analyses.

Preparation of gelatine film incorporated with different weight percentage of hydrolyzed $S C B$

To incorporate the hydrolyzed SCB, modification of methods by Nagarajan et al. (2014) and Gilfillan et al. (2014) were applied. Gelatine powder was mixed with distilled water to obtain the protein concentration of $3.5 \%(\mathrm{w} / \mathrm{v})$. The mixture was heated at $70^{\circ} \mathrm{C}$ until completely dissolved. Then, glycerol was added at concentrations of $35 \%(\mathrm{w} / \mathrm{w})$ of protein content as a plasticizer. Hydrolyzed SCB suspension of 0.00, 0.131, 0.262, 0.393 and $0.524 \mathrm{~g}$ (dry basis) to produce $0,2.5,5,7.5$ and $10 \%(\mathrm{w} / \mathrm{w}$, on dry protein basis) were 
prepared by homogenizing for $20 \mathrm{secs}$ at 11,000 rpm (IKA Labortechnik homogenizer, Selangor, Malaysia). The hydrolyzed SCB suspensions were added to the film forming solution slowly and the mixtures were homogenized for another $1 \mathrm{~min}$ at 11,000 rpm. The final volume of the film forming suspensions were made up to $150 \mathrm{ml}$ and were sonificated for 30 mins using sonicating bath (Elmasonic S $30 \mathrm{H}$, Singen, Germany) and stirred gently for $30 \mathrm{mins}$ at room temperature in order to obtain a homogeneous suspension. Before casting the film forming suspensions, they were degassed for $10 \mathrm{mins}$ using sonicating bath. The film was then prepared by casting $4.0 \mathrm{~g}$ film forming suspension onto a rimmed silicone resin plate $\left(50 \times 50 \mathrm{~mm}^{2}\right)$ and air-blown for $12 \mathrm{hrs}$ at room temperature before drying in an environmental chamber (WTB Binder, Tuttlingen, Germany) for $24 \mathrm{hrs}$ at $25^{\circ} \mathrm{C}$ and $50 \pm 5 \% \mathrm{RH}$. The resulting films were peeled off manually and subjected to analyses. Gelatine film without SCB (control) is named SCB 0 and those incorporated with 2.5, 5, 7.5 and 10\% SCB were named SCB 2.5, SCB 5.0, SCB 7.5 and SCB 10.0 respectively. Prior to testing, film samples were conditioned for $48 \mathrm{~h}$ at $25^{\circ} \mathrm{C}$ and $50 \pm 5 \% \mathrm{RH}$ (Ahmad et al., 2012).

\section{Determination of film properties}

\section{Film thickness}

The thickness of films were measured using a micrometer (Mitutoyo, Model ID-C112PM, Serial No. 00320, Mitutoyo Corp., Kawasaki-shi, Japan) as described by Fazilah and Maizura (2010). Measurements were taken at fifteen random positions around each film of 10 film samples and average value was calculated.

\section{Mechanical properties}

Tensile strength (TS) and elongation at break (EAB) of the films were determined as described by Iwata et al. (2000) using Universal Testing Machine (Lloyd Instruments, Hamsphire, UK). Five film samples $\left(2 \times 5 \mathrm{~cm}^{2}\right)$ were first conditioned for $48 \mathrm{hrs}$ at $25^{\circ} \mathrm{C}$ and $50 \pm 5 \% \mathrm{RH}$ before testing. The film samples were clamped under tensile loading using a $100 \mathrm{~N}$ load cell with initial grip length of $3 \mathrm{~cm}$ and cross-head speed at 30 $\mathrm{mm} / \mathrm{min}$. Tensile strength $(\mathrm{MPa})$ was calculated by dividing the maximum load $(\mathrm{N})$ needed to pull the sample film apart by the cross-sectional area of the sample. Percentage 
156 of elongation at break was calculated by the film elongation at the moment of rupture 157 divided with the initial grip length of samples multiplied by $100 \%$.

158

159

160

161

162

163

164

165

166

167

168

169

170

171

172

173

174

175

176

177

178

179

180

181

182

183

184

185

186

\section{Water Vapor Permeability (WVP)}

WVP of the films were determined using American Society for Testing and Materials (ASTM) method (ASTM, 2004) as described by Rattaya et al. (2009). The film was sealed on an aluminum permeation cup containing dried silica gel $(0 \% \mathrm{RH})$ with silicone vacuum grease and a rubber gasket was used to hold the film in place. The cups were placed in a desiccator containing distilled water at $30^{\circ} \mathrm{C}$. The aluminum permeation cups were weighed at every $1 \mathrm{hr}$ intervals for $8 \mathrm{hrs}$ period. WVP of film was calculated as follows:

$\operatorname{WVP}\left(\mathrm{gm}^{-1} \mathrm{~s}^{-1} \mathrm{~Pa}^{-1}\right)=w x A^{-1} \mathrm{t}^{-1}\left(P_{2}-P_{l}\right)^{-1}$

where, $w=$ weight gain of the cup (g); $x=$ film thickness (m); $A=$ area of exposed film $\left(\mathrm{m}^{2}\right) ; t=$ time of gain $(\mathrm{s})$, and $\left(P_{2}-P_{1}\right)=$ vapor pressure difference across the film $(\mathrm{Pa})$.

\section{Color measurement}

Color of each different film was determined using a CIE colorimeter (Hunter Associates Laboratory Inc., USA). Color of the film is expressed as $L^{*}$ - (lightness/brightness), $a^{*}$ (redness/greenness) and $b^{*}-$ (yellowness/blueness) values. The total difference in color $\left(\Delta E^{*}\right)$ was calculated according to the equation of Gennadios et al. (1996) as follows:

$$
\Delta E^{*}=\sqrt{\left(\Delta L^{*}\right)^{2}+\left(\Delta a^{*}\right)^{2}+\left(\Delta b^{*}\right)^{2}}
$$

where, $\Delta L^{*}, \Delta a^{*}$, and $\Delta b^{*}$ are the differences between the color parameter of the film samples and the color parameter of the white standard,

$\left(L^{*}=93.63, a^{*}=-0.88\right.$, and $\left.b^{*}=0.33\right)$ when test done on films with different glycerol

percentage, and

$\left(L^{*}=93.59, a^{*}=-0.95\right.$, and $\left.b^{*}=0.44\right)$ when test done on films incorporated with hydrolyzed sugarcane bagasse. 


\section{Light transmittance and transparency value}

189 Light transmittance of the films was measured in ultraviolet (UV) and visible range from $190200 \mathrm{~nm}$ to $800 \mathrm{~nm}$ using a UV-Visible spectrophotometer (model UV-1800, Shimadzu, 191 Kyoto, Japan) (Shiku et al., 2004). The transparency value of film sample was calculated 192 based on the equation of Han and Floros (1997) as shown below :

194 Transparency value $=\frac{\left(-\log T_{600}\right)}{x}$

195 where, $\mathrm{T}_{600}=$ the fractional transmittance at $600 \mathrm{~nm}$, and $x=$ the film thickness $(\mathrm{mm})$. The 196 higher the transparency value indicates the lower transparency of film.

199 Microstructure of surface and cross-section of film samples were determined as described 200 by Tongnuanchan et al. (2013) using scanning electron microscopy (SEM) (Quanta 400, 201 FEI, Eindhoven, the Netherlands). Film samples were fractured under liquid nitrogen before visualization for cross-section. The film samples were mounted on bronze stub and sputtered with gold using Sputter coater (SPI-Module, West-Chester, PA, USA) in order to make the sample conductive. Photographs were taken at an acceleration voltage of $15 \mathrm{kV}$.

\section{Statistical analysis}

208 Data were subjected to analysis of variance (ANOVA) and mean comparisons were carried out by Duncan's multiple range test. For pair comparison, T-test was used (Steel

210 and Torrie, 1980). Results are presented as mean \pm standard deviation and the probability 211 value of $\mathrm{p}<0.05$ is considered as significant. Where relevant, an asterisk $\left(^{*}\right)$ is used to 212 indicate which values are presented as mean \pm standard deviation. Statistical analysis 213 was performed using the Statistical Package for Social Sciences version 22.0 (IBM Corp. 214 Released 2013. IBM SPSS Statistics for Windows, NY). 
217 Films from gelatine with different percentage of glycerol were first produced, tested and

218 analyzed in order to determine which film is suitable to proceed to form films

219 incorporated with different weight percentage of SCB.

\section{Results and discussion}

Protein content in extracted chicken feet gelatine and moisture content of hydrolyzed SCB suspension The chicken feet gelatine contains about $74.22 \%$ of protein. The moisture content of the hydrolyzed SCB suspension was $98.63 \%$. The dry basis of the SCB was calculated by subtracting $98.63 \%$ with $100 \%$ which resulted in $1.37 \mathrm{~g}$. This means that there was 1.37 $\mathrm{g}$ of SCB for every $100 \mathrm{ml}$ of the hydrolyzed SCB suspension.

Properties of gelatine film with different percentage of glycerol

The thickness of films with different percentage of glycerol is as shown in Table 1. It is not significantly different) between the films containing $25 \%(0.058 \mathrm{~mm})$ and $35 \%$ glycerol $(0.060 \mathrm{~mm})$. The glycerol did not affect the film thickness as glycerol was dissolved with the gelatine during preparation of FFS. Negligible differences in thickness of gelatine-based films with different levels of glycerol were also mentioned by Vanin et al.(2005), Kokoszka et al. (2010), Tongnuanchan et al.(2012) and Chamnanvatckatit et al. 238 (2014).

Table 1. Properties of films from chicken feet gelatine with different percentage of

\section{Mechanical Properties}

TS and EAB of the film with different percentage of glycerol are as shown in Table 1. glycerol There is significant difference $(\mathrm{p}<0.05)$ for both TS and EAB. It can be seen that TS of the film decreased from 44.86 $\mathrm{MPa}$ to $34.20 \mathrm{MPa}$ when the glycerol percentage increased $10 \%$. As for the EAB of the film, the value increased about two-fold; from $15.99 \%$ to 
$33.30 \%$. Glycerol concentration affects the film properties by improving the film extensibility and reducing its resistance as reported by Jouki et al. (2013). Glycerol improves the flexibility of gelatine-based film but decreases its stiffness.

Chamnanvatckatit et al. (2014) stated that glycerol gives plasticizing effect because it decrease the inter- and intra molecular attractive forces resulting TS to decrease and $\mathrm{EAB}$ to increase with the increasing of glycerol concentration. Plasticizer can be easily inserted between polymer chains to produce a "cross-linker" effect that decreases the free volume of the polymer and at the same time improves the extensibility of the films and diminishes mechanical strength (Jouki et al., 2013). Other studies showed similar result concerning the effect of glycerol as plasticizer on protein-based films which include muscle proteins of Thai tilapia (Sobral et al., 2005), whey protein (Ramos et al., 2013) and bovine gelatine (Chamnanvatckatit et al., 2014).

\section{Water Vapor Permeability (WVP)}

WVP of the film prepared from chicken feet gelatine with $25 \%$ and $35 \%$ glycerol are shown in Table 1. There is no significant difference between the gelatine film with $25 \%$ and $35 \%$ glycerol. The WVP for $25 \%$ glycerol gelatine film is $2.04 \times 10^{-11} \mathrm{gm}^{-1} \mathrm{~s}^{-1} \mathrm{~Pa}^{-1}$ and $2.14 \times 10^{-11} \mathrm{gm}^{-1} \mathrm{~s}^{-1} \mathrm{~Pa}^{-1}$ for $35 \%$ glycerol gelatine film. WVP increases as the glycerol percentage increases. This is due to lower water barrier in higher content of glycerol.

Glycerol enhances the water vapor permeability as it modifies the molecular organization of the protein network and increases the free volume leading to lesser dense network hence, films are permeable to water as it ease the water diffusion (Al-Hassan and Norziah, 2012). Arvanitoyannis et al. (1998) stated that the water vapor transfer rate increases proportionally with the increasing of the total plasticizer content (water and polyols) in the polymer matrix.

Chamnanvatckatit et al. (2014) with similar results also stated that glycerol is hydrophilic in nature which led to the hygroscopic characteristics of the films thus increases the moisture content of the film as well as the WVP of the film. 


\section{Color measurement}

Differences in color between the gelatine film with $25 \%$ and $35 \%$ glycerol are presented in Table 2. As mentioned, $L^{*}$ is the lightness/brightness and $a^{*}$ is redness/greenness whereas $b^{*}$ is the yellowness/blueness values. The values of $L^{*}, a^{*}$ and $\Delta E^{*}$ have significant difference $(p<0.05)$ between the films from gelatine with $25 \%$ and $35 \%$ glycerol. However, the $b^{*}$ values showed no significant difference between the two types of films. Based on the study carried out by Chamnanvatckatit et al. (2014), addition of different concentrations of glycerol to bovine protein films does not impact the color of the resulting films. However, Jouki et al. (2013) reported otherwise, when different glycerol concentration were added to cress seed gum films. All of the color parameters except $a$-value of the films were significantly changed when glycerol concentration increased.

Table 2. Film colors made from chicken feet gelatine with different percentage of glycerol

\section{Light transmittance and transparency value}

The light transmission in the UV range (200-280 nm) for film with $25 \%$ glycerol is from $0.02 \%$ to $21.54 \%$ while film with $35 \%$ glycerol is from $0.03 \%$ to $19.25 \%$. As for visible range $(350-800 \mathrm{~nm})$, the light transmittance ranges from $72.48 \%$ to $87.58 \%$ and $66.75 \%$ to $85.62 \%$ for $25 \%$ and $35 \%$ glycerol gelatine-based film respectively (Table 3 ). This conveys that there is a slight decrease in light transmission with the increase of percentage of glycerol.

Table 3. Light transmittance and transparency values of films from chicken feet gelatine with different percentage of glycerol

In addition, the increased in percentage of glycerol had no significant differences on the transparency value between the two types of film. The transparency value differs by 0.02 indicating the increased in glycerol percentage do not affect the transparency value of the films. The resulting gelatine films were transparent and also clear which is 
suitable for use as see-through packaging. Gelatine has low content of tyrosine and phenylalanine; aromatic amino acids that are sensitive to chromophores which absorb light at wavelength below $300 \mathrm{~nm}$ (Li et al., 2006). The aromatic amino acids are important as an UV barrier property of protein films as gelatine film without glycerol has higher barrier for light transmission and UV range compared to film added with glycerol.

\section{Analysis}

Based on the results for thickness, mechanical properties, water vapor permeability, color and light transmittance as well as transparency value tests of the films from chicken feet gelatine with different percentage of glycerol, film with $35 \%$ glycerol was chosen to be incorporated with different weight percentage of hydrolyzed SCB. Film with $35 \%$ of glycerol has lower TS but higher EAB. By incorporating hydrolyzed SCB, it was hoped that the TS increases and WVP of the film can further be lowered.

Properties of films from chicken feet gelatine incorporated with different percentage of dry weight $S C B$

\section{Thickness}

Thickness of the film incorporated with different percentage of dry weight SCB is shown in Table 3. Generally, thickness of a film increases as the amount of weight percentage of SCB increases $(p<0.05)$. The hydrolyzed SCB is likely distributed on the gelatine film and increase the thickness of the film. However, the thickness of the film is the same between the control film with $0 \%$ and $2.5 \%$ of dry weight SCB. There is no effect on the thickness of the film as the amount of SCB is not significant.

Table 4. Properties of films from chicken feet gelatine incorporated with different percentage of dry weight SCB

\section{Mechanical Properties}

The mechanical properties of films incorporated with different percentage of dry weight SCB are presented in Table 4. Incorporating SCB in the gelatine film is supposed to increase the TS of the film. However, as shown in Table 4, the TS increased slightly from 
22.50 MPa to 23.07 MPa for the film with $0 \mathrm{wt} \%$ and $5.0 \mathrm{wt} \% \mathrm{SCB}$ respectively. The TS then decreased to $20.88 \mathrm{MPa}$ and $19.76 \mathrm{MPa}$ with $7.5 \mathrm{wt} \%$ and $10.0 \mathrm{wt} \% \mathrm{SCB}$ incorporated respectively. This is in agreement with Gilfillan et al. (2012) and Prachayawarakorn et al. (2010) where fiber overloading resulted in decreasing tensile strength.

EAB of films decreases as the amount of percentage of dry weight SCB increases as shown in Table 4 . The EAB of film decreased steadily from $59.97 \%$ to $24.82 \%$ for the film with 0 wt \% and 10.0 wt \% of SCB respectively. Slavutsky and Bertuzzi (2014) reinforced starch films with cellulose nanocrystals obtained from sugarcane bagasse and stated high value of TS as the sugarcane bagasse was dispersed properly in the matrix structure. In addition, EAB value decreases due to the rigid nature of the sugarcane bagasse. Another similar study was conducted by Gilfillan et al. (2014) where starch was incorporated with sugarcane bagasse nanofibres. The TS doubled but started to decrease at fibre loadings above $10 \mathrm{wt} \%$ while EAB decreased by up to $70 \%$ compared to film with no nanofibres.

\section{Water Vapor Permeability (WVP)}

WVP of films from chicken feet gelatine incorporated with different weight percentage of SCB showed significant differences $(p<0.05)$ between the films (Table 4). WVP of films decreased with the increasing levels of weight percentage of SCB incorporated in the film. The WVP of the films decreased from $2.18 \times 10^{-11} \mathrm{gm}^{-1} \mathrm{~s}^{-1} \mathrm{~Pa}^{-1}$ to $1.56 \times 10^{-11} \mathrm{gm}^{-1} \mathrm{~s}^{-1} \mathrm{~Pa}^{-1}$ which is the SCB 0 (control) to SCB 10.0 (10 wt \% SCB), which are the highest and lowest WVP of the films respectively. However, there is no significant difference between SCB 7.5 and SCB 10.0. This may due to the uneven dispersion of SCB on the film samples for $7.5 \mathrm{wt} \%$ and $10.0 \mathrm{wt} \%$.

A high WVP of film is not desirable due to its usage and performance (Pereda et al., 2011). From the results in this experiment, addition of hydrolyzed SCB improved the water vapor barrier properties of the film slightly. Rawdkuen et al. (2012) reported similar results by adding catechin-lysozyme combination (CLC) in fish gelatine film. The barrier properties improved as the moisture transfer between the food and the surrounding atmosphere is lowered when the film was applied to heterogeneous food product. Ahmad 
370 et al. (2012) stated that the water vapor transfer process in films depends on the 371 hydrophilic-hydrophobic ratio of the film constituents. In addition, film thickness also 372 influences the water vapor permeability as thicker film can absorb more water from the 373 environment (Rawdkuen et al., 2010). In order to utilise the gelatine based bio film 374 incorporated with SCB as a potential food packaging film, resistance of the film to water 375 is desirable if the film is to be used for the preservation of intermediate or high moisture 376 foods (Ozdemi and Floros, 2008). Films with good solubility had been proposed as 377 packaging material for instant noodle seasoning bags and instant beverages or as casing 378 for sausages, biscuits and candy (Wan et al., 2015). The water solubility and swelling of 379 the bio film should be determined in future studies.

\section{Color measurement}

382 The color properties, $L^{*}$ (lightness/brightness), $a^{*}$ (redness/greenness) and $b^{*}$ 383 (yellowness/blueness) values of the films from chicken feet gelatine incorporated with 384 different levels of weight percentage of SCB are shown in Table 5. It can be concluded 385 that all the color parameters were affected by the amount of weight percentage of SCB 386 being incorporated in the film. The value increases proportionally with the weight 387 percentage of SCB and there is significant difference $(p<0.05)$ for the three parameters. 388 The total color differences $\left(\Delta E^{*}\right)$ also showed significant difference $(\mathrm{p}<0.05)$. Control 389 (SCB 0) showed the lowest value while the highest weight percentage (SCB 10.0) 390 showed the highest value with 3.48 and 3.61 respectively. 
Table 5. Film colors of chicken feet gelatine incorporated with different percentage of dry weight SCB

\section{Light transmittance and transparency value}

Generally, films often exhibit lower light transmission in the UV range than in the visible range (Rawdkuen et al., 2012). Transmission of UV light of the film from control film to incorporation of sugarcane bagasse (SCB 10.0) in chicken feet gelatine film at $280 \mathrm{~nm}$ decreased from 22.20 to $9.95 \%$. Hence, the films are successful in preventing the UV light and possibly retard lipid oxidation induced by the UV light. The light transmittance of the films at different wavelengths decreases as the weight percentage of the SCB incorporated in the film increases (Table 6).

Table 6. Light transmittance and transparency of films from chicken feet gelatine incorporated with different percentage of dry weight SCB

There is significant difference $(\mathrm{p}<0.05)$ on the transparency among all the films with different weight percentage of SCB. The transparency value increases as the amount of weight percentage of SCB incorporated increases. Transparency value increased from 0.99 (SCB 0) to 2.37 (SCB 10.0)with higher transparency value indicating that the films have lower transparency. The increase of transparency value is most probably due to the hydrolyzed SCB incorporated as the hydrolyzed SCB is solid and not transparent which made the film not entirely clear.

\section{Scanning Electron Microscopy (SEM)}

SEM micrographs of the surface and cross-section of films from chicken feet gelatine incorporated with different levels of weight percentage of hydrolyzed SCB are illustrated in Figure 1.

Figure 1. Scanning Electron Microscopy micrographs of surface (magnification: 500x) and cross section (magnification: 1800x) of films from chicken feet gelatine incorporated with different levels of weight percentage of SCB. The SCB 0 which is the control film 
showed smooth and homogeneous surface. The cross-section of the control film also showed smooth surface. As the weight percentage of hydrolyzed SCB increases, the surface of the films showed increment in white spots. The white spots are believed to be the hydrolyzed SCB.

The SCB 0 which is the control film showed smooth and homogeneous surface. As the weight percentage of hydrolyzed SCB increases, the surface of the films showed increment in white spots. The white spots are believed to be the hydrolyzed SCB. The cross-section of control film also showed smooth surface. The surface became rougher with the increase of weight percentage of SCB. However, through the micrographs, it can be deduced that the hydrolyzed SCB did not form a strong matrix with the protein matrix of gelatine. There is a weak bond between the SCB and the gelatine film and the hydrolyzed SCB merely formed a layer on top of the gelatine film. It can be seen that the hydrolyzed SCB did not disperse homogeneously on the gelatine film but agglomerate instead. Hence, further treatment of the SCB should be applied for a better dispersion of the SCB on the gelatine-based film.

Gilfillan et al. (2014) reported that the sugarcane nanofibres are well attached to the starch matrix based on the SEM micrographs of the composite from starch with SCB nanofibres. The SEM micrograph of starch film reinforced with cellulose nanocrystals obtained from SCB showed that the dispersion of the cellulose nanocrystals are homogeneous within the polymer matrix (Slavutsky and Bertuzzi, 2014). In this study, the SCB used were chemically hydrolyzed. The SCB particle size is still noticeably large (Figure 1). This may have affected the dispersion of the SCB on the gelatine film. The structure of cellulose fibers can be damaged by excessive hydrolysis (Gilfillan et al., 2014). It is suggested that further treatments be carried out on hydrolyzed SCB. Pretreatment (Salehudin et al., 2013) and combination of mechanical refining and enzymatic treatment were found to produce homogenous nanofibrils from sugarcane bagasse (Santucci et al., 2016).

\section{Conclusion}


A higher percentage of glycerol used in the gelatine-based film, resulted in lower TS and higher EAB. Film containing 35\% glycerol in gelatine extracted from chicken feet were further incorporated with different weight percentage $(0,2.5,5.0,7.5$ and $10.0 \mathrm{wt} \%)$ of SCB. Although the mechanical strength of the film could not be improved by incorporating SCB, there was only slight improvement in the WVP barrier properties. As the weight percentage of SCB increases, the WVP of the film decreases. In addition, film from gelatine extracted from chicken feet incorporated with $5.0 \mathrm{wt} \%$ of SCB has the best properties when all the tests were taken into consideration. The thickness, color and transparency value of the film with $5.0 \mathrm{wt} \%$ of SCB were similar to the control film. However, the TS of SCB 5.0 film is increased and the WVP is lowered slightly. This limits the application of the film as biomaterial and further research to treat the hydrolysed SCB is recommended. The bio-film developed in this study incorporates sugarcane bagasse into the film derived from chicken feet and demonstrated an increment in tensile strength and reduction of water vapor permeability. This study is of value to food practitioners looking into utilising agricultural wastes (e.g. animal by-product and sugarcane bagasse).

\section{References}

Abraham, E., Deepa, B., Pothan, L.A., Jacob, M., Thomas, S., Cvelbar, U., and Anandjiwala, R. (2011). "Extraction of nanocellulose fibrils from lignocellulosic fibres: A novel approach", Carbohydrate Polymers, Vol. 86 No. 4, 1468-1475.

Afra, E., Yousefi, H., Hadilam, M.M., and Nishino, T. (2013). "Comparative effect of mechanical beating and nanofibrillation of cellulose on paper properties made from bagasse and softwood pulps", Carbohydrate Polymers, Vol. 97 No. 2, 725730.

AOAC. (2000). Official methods of analysis, 17th ed. Association of Official Analytical Chemists, Gaithersberg, MD.

Ahmad, M., Benjakul, S., Prodpran, T., and Agustini, T.W. (2012). "Physico-mechanical andantimicrobial properties of gelatine film from the skin of unicorn leatherjacket incorporated with essential oils", Food Hydrocolloids, Vol. 28, 189-199.

Al-Hassan, A.A., and Norziah, M.H. (2012). "Starch-gelatine edible films: Water vapor permeability and mechanical properties as affected by plasticizers. Food Hydrocolloids, Vol. 26 No. 1, 108-117.

Arvanitoyannis, I., Nakayama, A., and Aiba, S. (1998). "Edible films made from hydroxypropyl starch and gelatine and plasticized by polyols and water", Carbohydrate Polymers, Vol. 36, 105-119.

ASTM Standard D6400. (2004). Standard Specification for Compostable Plastics. ASTM International. West Conshohocken, Pennsylvania. 
Badii, F., and Howell, N.K. (2006). "Fish gelatin: structure, gelling properties and interaction with egg albumen proteins", Food Hydrocolloids, Vol. 20, 630-640.

Bergo, P.V.A., Carvalho, R.A., Sobral, P.J.A, dos Santos, R.M.C., da Silva, F.B.R, Prison, J.M., Solorza-Feria, J., and Habitante, A.M.Q.B. (2008). "Physical properties of edible films based on cassava starch as affected by the plasticizer concentration", Packaging Technology and Science, Vol. 21 No. 2, 85-89.

Cerqueira, D.A., Filho, G.R., and Meireles, C.d.S. (2007). "Optimization of sugarcane bagasse cellulose acetylation", Carbohydrate Polymers, Vol. 69 No. 3, 579-582.

Chamnanvatckatit, P., Prodpran, T., and Benjakul, S. (2014). "Some characteristics of bovine gelatine and its film properties as influenced by glycerol", Research Journal of Chemical and Environmental Sciences, Vol. 2 No. 3, 32-39.

Chen, W., Yu, H., Liu, Y., Chen, P., Zhang, M., and Hai, Y. (2011). "Individualization of cellulose nanofibers from wood using high-intensity ultrasonication combined with chemical pretreatments", Carbohydrate Polymers, Vol. 84 No. 4, 1804-1811.

Davis, G., and Song, J.H. (2006). "Biodegradable packaging based on raw materials from crops and their impact on waste management", Industrial Crops and Products, Vol. 23 No. 2, 147.

Deconinck, S., and Wilde, B.D.E. (2013). Benefits and challenges of bio- and oxodegradable plastics: A comparative literature study. Retrieved 18 January 2016, from http://ows.be/wp-content/uploads/2013/10/Final-Report-DSL-1_Rev02.pdf

Fazilah, A., and Maizura, M. (2010). Study on the physical and microbial properties of edible film incorporated with lemongrass (Cymbopogon citratus) oil. In F.Y. Chye, J.S. Lee (Eds.), Current Research in Food Science and Nutrition. Sabah: Penerbit UMS. p. 131-141.

Freudenrich, C. (2007). How plastics work. Retrieved 22 March 2016, from http://science.howstuffworks.com/plastic.htm

Gennadios, A., Weller, C.L., Hanna, M.A., and Froning, G.W. (1996). "Mechanical and barrier properties of egg albumen films", Journal of Food Science, Vol. 61 No. 3, 585-589.

Gilfillan, W.N., Moghaddam, L., and Doherty, W.O.S. (2014). "Preparation and characterization of composites from starch with sugarcane bagasse nanofibers", Cellulose, Vol. 21 No. 4, 2695-2712.

Grommuang, F., Kijroongrojana, K., and Vittayanont, M. (2006). Extraction and characterization of gelatine from chicken feet. Proceedings of the First Joint PSU-UNS International Conference on BioScience: Food, Agriculture and Environment. Hat Yai, Songkhla, Thailand, August 17-19, 2006.

Han, J. H., and Floros, J. D. (1997). "Casting antimicrobial packaging films and measuring their physical properties and antimicrobial activity", Journal of Plastic Film and Sheet, Vol. 13, 287-298.

Hiloidhari, M., Das, D., and Baruah, D.C. (2014). "Bioenergy potential from crop residue biomass in India”, Renewable and Sustainable Energy Reviews, Vol. 32, 504-512.

Hopewell, J., Dvorak, R., and Kosior, E. (2009). "Plastics recycling: Challenges and opportunities", Philosophical Transactions of the Royal Society of London. Series B, Biological Sciences, Vol. 364 No. 1526, 2115-2126. 
Hoque, M.S., Benjakul, S., and Prodpran, T. (2011). "Properties of film from cuttlefish (Sepia pharaonis) skin gelatine incorporated with cinnamon, clove and star anise extracts", Food Hydrocolloids, Vol. 25 No. 5, 1085-1097.

Iwata, K., Ishizaki, S., Handa, A., and Tanaka, M. (2000). "Preparation and characterization of edible films from fish water-soluble proteins", Fisheries Science, Vol. 66 No. 2, 372-378.

Jongjareonrak, A., Benjakul, S., Visessanguan, W., Prodpran, T., and Tanaka, M. (2006). "Characterization of edible films from skin gelatine of brownstripe red snapper and bigeye snapper", Food Hydrocolloids, Vol. 20 No. 4, 492-501.

Jouki, M., Khazaei, N., Ghasemlou, M., and Hadinezhad, M. (2013). "Effect of glycerol concentration on edible film production from cress seed carbohydrate gum", Carbohydrate Polymers, Vol. 96 No. 1, 39-46.

Jridi, M., Souissi, N., Mbarek, A., Chadeyron, G., Kammoun, M. and Nasri, M. (2013). "Comparative study of physico-mechanical and antioxidant properties of edible gelatin films from the skin of cuttlefish", International Journal of Biological Macromolecules, Vol. 61, 17-25.

Jun, M., Leem J.M., Lee, K.S., and Kim, K.O. (2000). "The effect of preparation conditions on the properties of Jokpyun (traditional Korean gel type food) model system", Food Science and Biotechnology, Vol. 9 No. 27, 27-31.

Kaewruang, P., Benjakul, S., Prodpran, T., and Nalinanon, S. (2013). "Physicochemical and functional properties of gelatin from the skin of unicorn leatherjacket (Aluterus monoceros) as affected by extraction conditions", Food Bioscience, Vol. 2, 1-9.

Kokoszka, S., Debeaufort, F., Hambleton, A., Lenart, A., and Voilley, A. (2010). "Protein and glycerol contents affect physico-chemical properties of soy protein isolate-based edible films", Innovative Food Science and Emerging Technologies, Vol. 11 No. 3, 503-510.

Li, B., Kennedy, J.F., Peng, J.L., Yie, X., and Xie, B.J. (2006). "Preparation and performance evaluation of glucomannan-chitosan-nisin ternary antimicrobial blend film", Carbohydrate Polymers, Vol. 65 No. 4, 488-494.

Lim, J.Y., Oh, S.S. and Kim, K.O. (2001). "The effects of processing conditions on the properties of chicken feet gelatin", Food Science and Biotechnology, Vol. 10 No. 6, 638-645.

Nagarajan, M., Benjakul, S., Prodpran, T., and Songtipya, P. (2014). "Characteristics of bio-nanocomposite films from tilapia skin gelatine incorporated with hydrophilic and hydrophobic nanoclays", Journal of Food Engineering, Vol. 143 No. 2014, 195-204.

Nikoo, M., Benjakul, S., Bashari, M., Alekhorshied, M., Idrissa, C., Yang, N., and Xu, X. (2014). "Physicochemical properties of skin gelatin from farmed Amur sturgeon (Acipenser schrenckii) as influenced by acid pretreatment", Food Bioscience, Vol. 5, 19-26.

Otoni, C. G., Avena-Bustillos, R. J., Olsen, C. W., Bilbao-Sainz, C., and McHugh, T. H. (2016). "Mechanical and water barrier properties of isolated soy protein composite edible films as affected by carvacrol and cinnamaldehyde micro and nanoemulsions", Food Hydrocolloids, Vol. 57, 72-79. 
Ozdemir, M., and Floros, J. M. (2008). "Optimization of whey protein films containing preservatives for water vapor permeability, water solubility and sensory characteristics", Journal of Food Engineering, Vol. 86 No. 2, pp. 215-224.

Pereda, M., Ponce, A.G., Marcovich, N.E., Ruseckaite, R.A., and Martucci, J.F. (2011). "Chitosan-gelatine composites and bi-layer films with potential antimicrobial activity", Food Hydrocolloids Vol. 25 No. 2011, 1372-1381.

Prachayawarakorn, J., Sangnitidej, P., and Boonpasith, P. (2010). "Properties of thermoplastic rice starch composites reinforced by cotton fiber or low-density polyethylene", Carbohydrate Polymers, Vol. 81 No.2, 425-433.

Prodpran, T., Benjakul, S., and Artharn, A. (2007). "Properties and microstructure of protein-based film from round scad (Decapterus maruadsi) muscle as affected by palm oil and chitosan incorporation", International Journal of Biological Macromolecules, Vol. 41 No. 5, 605-614.

Rafieian, F., Keramat, J., and Shahedi, M. (2015). "Physicochemical properties of gelatin extracted from chicken deboner residue", LWT-Food Science and Technology, Vol. 64 No. 2, 1370-1375.

Ramos, Ó.L., Silva, S. I., Soares, J. C., Fernandes, J.C., Pocas, M. F., Pintado, M. E., and Malcata, F. X. (2012). "Features and performance of edible films, obtained from whey protein isolate formulated with antimicrobial compounds", Food Research International, Vol. 45 No. 1, 351-361.

Ramos, Ó.L., Reinas, I., Silva, S.I., Fernandes, J.C., Cerqueira, M.A., Pereira, R.N. Vicente, A.A., Pocas, M.F., Pintado, M.E., and Malcata, F.X. (2013). "Effect of whey protein purity and glycerol content upon physical properties of edible films manufactured therefrom", Food Hydrocolloids, Vol. 30 No. 1, 110-122.

Rattaya, S., Benjakul, S., and Prodpran, T. (2009). "Properties of fish skin gelatine film incorporated with seaweed extract", Journal of Food Engineering, Vol. 95 No. 1, 151-157.

Rawdkuen, S., Sai-UT, S., and Benjakul, S. (2010). "Properties of gelatine films from giant catfish skin and bovine bone: a comparative study", European Food Research and Technology, Vol. 231 No. 6, 907-916.

Rawdkuen, S., Suthiluk, P., Kamhangwong, D., and Benjakul, S. (2012). "Mechanical, physico-chemical, and antimicrobial properties of gelatine-based film incorporated with catechin-lysozyme", Chemistry Central Journal, Vol. 6, 131.

Rubilar, J.F., Zuniga, R.N., Osorio, F., and Pedreschi, F. (2015). "Physical properties of emulsion-based hydroxypropyl methylcellulose/whey protein isolate (HPMC/WPI) edible films", Carbohydrate Polymers, Vol. 123, 27-38.

Sae-Leaw, T., and Benjakul, S. (2015). "Physico-chemical properties and fishy odour of gelatin from seabass (Lates calcarifer) skin stored in ice", Food Bioscience, Vol. $10,59-68$.

Salehudin, M.H., Salleh, E., Mamat, S.N.H., and Muhamad, I.I. (2014). "Starch based active packaging film reinforced with empty fruit bunch (EFB) cellulose nanofiber", Procedia Chemistry, Vol. 9, 23-33.

Santucci, B.S., Bras, J., Belgacem, M.N., da Silva Curvelo, A.A., and Pimenta, M.T.B. (2016). "Evaluation of the effects of chemical composition and refining treatments on the properties of nanofibrillated cellulose films from sugarcane bagasse", Industrial Crops and Products, Vol. 91, 238-248. 
Sarbon, N.M., Badii, F., and Howell, N.K. (2013). "Preparation and characterisation of chicken skin gelatin as an alternative to mammalian gelatin", Food Hydrocolloids, Vol. 30 No. 1, 143-151.

Sharma, L., and Singh, C. (2016). "Sesame protein based edible films: Development and characterization", Food Hydrocolloids, Vol. 61, 139-147.

Shiku, Y., Hamaguchi, P. Y., Benjakul, S., Visessanguan, W., and Tanaka, M. (2004). "Effect of surimi quality on properties of edible films based on Alaska pollack", Food Chemistry, Vol. 86 No. 4, 493-499.

Slavutsky, A. M., and Bertuzzi, M. A. (2014). "Water barrier properties of starch film reinforced with cellulose nanocrystals obtained from sugarcane bagasse", Carbohydrate Polymers, Vol. 110, 53-61.

Sobral, P.J.A., Santos, J.S., and García, F.T. (2005). "Effect of protein and plasticizer concentrations in film forming solutions on physical properties of edible films based on muscle proteins of a Thai Tilapia", Journal of Food Engineering, Vol. 70 No. 1, 93-100.

Song, J.H., Murphy, R.J., Narayan, R., and Davies, G.B.H. (2009). "Biodegradable and compostable alternatives to conventional plastics", Philosophical Transactions of the Royal Society of London. Series B, Biological Sciences, Vol. 364 No. 1526, 2127-2139.

Soni, A., Kandeepan, G., Mendiratta, S. K., Shukla, V., and Kumar, A. (2016). "Development and characterization of essential oils incorporated carrageenan based edible film for packaging of chicken patties", Nutrition and Food Science, Vol. 46 No. 1, 82-95.

Steel, R.G.D., and Torrie, J.H. (1980). Principles and procedures of statistics. New York: McGraw-Hill Book.

Sun, J.X., Sun, X.F., Zhao, F., and Sun, R.C. (2004). "Isolation and characterization of cellulose from sugarcane bagasse", Polymer Degradation and Stability, Vol. 84 No. 2, 331-339.

Szabo, T. L. (2005). Plastics - Microstructure and engineering applications. Retrieved 18 January 2016 from doi:10.1016/B978-075065148-6/50001-5

Teixeira, E.D.M., Bondancia, T.J., Teodoro, K.B.R., Corrêa, A.C., Marconcini, J.M., and Mattoso, L.H.C. (2011). "Sugarcane bagasse whiskers: Extraction and characterizations", Industrial Crops and Products, Vol. 33 No. 1, 63-66.

Tongnuanchan, P., Benjakul, S., and Prodpran, T. (2012). "Properties and antioxidant activity of fish skin gelatine film incorporated with citrus essential oils", Food Chemistry, Vol. 134 No. 3, 1571-1579.

Tongnuanchan, P., Benjakul, S., and Prodpran, T. (2013). "Physico-chemical properties, morphology and antioxidant activity of film from fish skin gelatine incorporated with root essential oils", Journal of Food Engineering, Vol. 117 No. 3, 350-360.

Vanin, F.M., Sobral, P.J.A., Menegalli, F.C., Carvalho, R.A., and Habitante, A.M.Q.B. (2005). "Effects of plasticizers and their concentrations on thermal and functional properties of gelatine-based films", Food Hydrocolloids, Vol. 19 No. 5, 899-907.

Wan, J., Liu, C., Liu, W., Tu, Z., Wu, W., and Tan, H. (2015). "Optimization of instant edible films based on dietary fiber processed with dynamic high pressure microfluidization for barrier properties and water solubility", $L W T$ - Food Science and Technology, Vol. 60 No.1, 603-608. 
Webb, H., Arnott, J., Crawford, R., and Ivanova, E. (2012). "Plastic degradation and its environmental implications with special reference to poly(ethylene terephthalate)", Polymers, Vol. 5 No. 1, 1-18.

Weng, W., Zheng, H., and Su, W. (2014). "Characterization of edible films based on tilapia (Tilapia zillii) scale gelatin with different extraction $\mathrm{pH}$ ", Food Hydrocolloids, Vol. 41, 19-26.

Zhang, Q., Wang, Q., Lv, S., Lu, J., Jiang, S., Regenstein, J. M., and Lin, L. (2016). "Comparison of collagen and gelatin extracted from the skins of Nile tilapia (Oreochromis niloticus) and channel catfish (Ictalurus punctatus)", Food Bioscience, Vol. 13, 41-48. 
Table 1 Properties of films from chicken feet gelatine with different percentage of glycerol

\begin{tabular}{ccccc}
\hline $\begin{array}{c}\text { Glycerol } \\
(\%)\end{array}$ & $\begin{array}{c}\text { Thickness } \\
(\mathbf{m m})\end{array}$ & $\begin{array}{c}\text { TS } \\
\mathbf{( M P a )}\end{array}$ & $\begin{array}{c}\text { EAB } \\
\mathbf{( \% )}\end{array}$ & $\begin{array}{c}\text { WVP } \\
\left(\mathbf{\times 1 0} \mathbf{- 1 1}_{\mathbf{g m}}^{\mathbf{- 1}} \mathbf{s}^{-\mathbf{1}} \mathbf{P a}^{\mathbf{- 1}} \mathbf{)}\right.\end{array}$ \\
\hline $25 \%$ & $0.058 \pm 0.003^{\mathrm{a}}$ & $44.86 \pm 1.66^{\mathrm{a}}$ & $15.99 \pm 6.24^{\mathrm{a}}$ & $2.04 \pm 0.29^{\mathrm{a}}$ \\
$35 \%$ & $0.060 \pm 0.003^{\mathrm{a}}$ & $34.20 \pm 0.97^{\mathrm{b}}$ & $33.30 \pm 6.79^{\mathrm{b}}$ & $2.14 \pm 0.11^{\mathrm{a}}$ \\
\hline
\end{tabular}

Results are presented as mean $\pm \mathrm{sd}$. Different superscript letters in the same column indicate significant difference by independent samples T-test $(\mathrm{p}<0.05)$.

TS - Tensile strength

EAB - Elongation at break

WVP - Water vapor permeability 
Table 2 Film colors made from chicken feet gelatine with different percentage of glycerol

\begin{tabular}{ccccc}
\hline $\begin{array}{c}\text { Glycerol } \\
(\%)\end{array}$ & $\boldsymbol{L}^{*}$ & $\boldsymbol{a}^{*}$ & $\boldsymbol{b}^{*}$ & $\Delta \boldsymbol{E}^{*}$ \\
\hline $25 \%$ & $90.77 \pm 0.06^{\mathrm{a}}$ & $-1.30 \pm 0.04^{\mathrm{a}}$ & $3.01 \pm 0.27^{\mathrm{a}}$ & $3.94 \pm 0.14^{\mathrm{a}}$ \\
$35 \%$ & $91.29 \pm 0.10^{\mathrm{b}}$ & $-1.40 \pm 0.03^{\mathrm{b}}$ & $3.18 \pm 0.07^{\mathrm{a}}$ & $3.73 \pm 0.08^{\mathrm{b}}$
\end{tabular}

Results are presented as mean \pm sd. Different superscript letters in the same column indicate significant difference by independent samples T-test $(p<0.05)$ 
Table 3 Light transmittance and transparency values of films from chicken feet gelatine with different percentage of glycerol.

\begin{tabular}{cccccccccc}
\hline $\begin{array}{c}\text { Glycerol } \\
(\%)\end{array}$ & \multicolumn{6}{c}{ Light transmittance (\%) at different wavelength (nm) } & Transparency \\
\cline { 2 - 9 } & $\mathbf{2 0 0}$ & $\mathbf{2 8 0}$ & $\mathbf{3 5 0}$ & $\mathbf{4 0 0}$ & $\mathbf{5 0 0}$ & $\mathbf{6 0 0}$ & $\mathbf{7 0 0}$ & $\mathbf{8 0 0}$ & value* $^{*}$ \\
\hline $25 \%$ & 0.02 & 21.54 & 72.48 & 79.94 & 84.30 & 85.96 & 86.89 & 87.58 & $1.08 \pm 0.05^{\mathrm{a}}$ \\
$35 \%$ & 0.03 & 19.25 & 66.75 & 74.95 & 80.54 & 83.02 & 84.53 & 85.62 & $1.10 \pm 0.14^{\mathrm{a}}$ \\
\hline
\end{tabular}

*Mean \pm SD
Different superscript letters in the same column indicate significant difference by
independent samples T-test $(\mathrm{p}<0.05)$. 
Table 4 Properties of films from chicken feet gelatine incorporated with different percentage of dry weight SCB

\begin{tabular}{|c|c|c|c|c|}
\hline Film sample & $\begin{array}{l}\text { Thickness } \\
\text { (mm) }\end{array}$ & $\begin{array}{c}\text { TS } \\
(\mathrm{MPa})\end{array}$ & $\begin{array}{l}\text { EAB } \\
(\%)\end{array}$ & $\begin{array}{c}\text { WVP } \\
\left(\times 10^{-11} \mathrm{gm}^{-1} \mathrm{~s}^{-1} \mathrm{~Pa}^{-1}\right)\end{array}$ \\
\hline SCB 0 & $0.066 \pm 0.002^{\mathrm{a}}$ & $22.50 \pm 1.97^{\mathrm{bc}}$ & $59.97 \pm 5.83^{\mathrm{c}}$ & $2.18 \pm 0.08^{\mathrm{d}}$ \\
\hline SCB 2.5 & $0.066 \pm 0.003^{\mathrm{a}}$ & $22.68 \pm 1.14^{\mathrm{c}}$ & $41.67 \pm 4.95^{\mathrm{b}}$ & $2.06 \pm 0.04^{\mathrm{c}}$ \\
\hline SCB 5.0 & $0.073 \pm 0.004^{\mathrm{b}}$ & $23.07 \pm 0.67^{\mathrm{c}}$ & $35.75 \pm 3.59^{b}$ & $1.85 \pm 0.08^{\mathrm{b}}$ \\
\hline SCB 7.5 & $0.085 \pm 0.004^{\mathrm{c}}$ & $20.88 \pm 1.36^{\mathrm{ab}}$ & $27.99 \pm 3.46^{\mathrm{a}}$ & $1.61 \pm 0.07^{\mathrm{a}}$ \\
\hline SCB 10.0 & $0.087 \pm 0.007^{\mathrm{c}}$ & $19.76 \pm 0.67^{\mathrm{a}}$ & $24.82 \pm 4.50^{\mathrm{a}}$ & $1.56 \pm 0.05^{\mathrm{a}}$ \\
\hline
\end{tabular}

Results are presented as mean \pm sd. Different superscript letters in the same column indicate significant difference by Duncan's multiple range tests $(\mathrm{p}<0.05)$.

TS - Tensile strength

EAB - Elongation at break

WVP - Water vapour permeability

SCB: Sugarcane bagasse 
Table 5 Film colors of chicken feet gelatine incorporated with different percentage of dry weight SCB

\begin{tabular}{lcccc}
\hline $\begin{array}{l}\text { Film } \\
\text { sample }\end{array}$ & $\boldsymbol{L}^{*}$ & $\boldsymbol{a}^{*}$ & $\boldsymbol{b}^{*}$ & $\Delta \boldsymbol{E}^{*}$ \\
\hline SCB 0 & $90.85 \pm 0.07^{\mathrm{a}}$ & $-1.30 \pm 0.06^{\mathrm{a}}$ & $2.61 \pm 0.21^{\mathrm{a}}$ & $3.48 \pm 0.06^{\mathrm{a}}$ \\
SCB 2.5 & $90.86 \pm 0.09^{\mathrm{a}}$ & $-1.25 \pm 0.04^{\mathrm{b}}$ & $2.75 \pm 0.12^{\mathrm{b}}$ & $3.57 \pm 0.05^{\mathrm{b}}$ \\
SCB 5.0 & $91.01 \pm 0.16^{\mathrm{b}}$ & $-1.24 \pm 0.03^{\mathrm{b}}$ & $2.90 \pm 0.21^{\mathrm{c}}$ & $3.58 \pm 0.04^{\mathrm{b}}$ \\
SCB 7.5 & $91.26 \pm 0.02^{\mathrm{c}}$ & $-1.23 \pm 0.03^{\mathrm{b}}$ & $3.22 \pm 0.08^{\mathrm{d}}$ & $3.59 \pm 0.06^{\mathrm{b}}$ \\
SCB 10.0 & $91.55 \pm 0.08^{\mathrm{d}}$ & $-1.21 \pm 0.07^{\mathrm{b}}$ & $3.40 \pm 0.06^{\mathrm{e}}$ & $3.61 \pm 0.07^{\mathrm{b}}$ \\
\hline
\end{tabular}

Results are presented as mean \pm sd. Different superscript letters in the same column indicate significant difference by Duncan's multiple range tests $(\mathrm{p}<0.05)$.

SCB: Sugarcane bagasse 
Table 6 Light transmittance and transparency of films from chicken feet gelatine incorporated with different percentage of dry weight SCB.

\begin{tabular}{|c|c|c|c|c|c|c|c|c|c|}
\hline \multirow{2}{*}{$\begin{array}{l}\text { Film } \\
\text { sample }\end{array}$} & \multicolumn{8}{|c|}{ Light transmittance (\%) at different wavelength (nm) } & \multirow{2}{*}{$\begin{array}{c}\text { Transparency } \\
\text { value* }\end{array}$} \\
\hline & 200 & 280 & 350 & 400 & 500 & 600 & 700 & 800 & \\
\hline SCB 0 & 0.02 & 22.20 & 73.13 & 80.35 & 84.35 & 85.94 & 86.83 & 87.43 & $0.99 \pm 0.09^{\mathrm{a}}$ \\
\hline SCB 2.5 & 0.02 & 19.88 & 68.94 & 76.91 & 81.08 & 82.62 & 83.54 & 84.23 & $1.06 \pm 0.09^{\mathrm{a}}$ \\
\hline $\mathrm{SCB}$ & 0.04 & 17.23 & 63.44 & 72.65 & 77.07 & 78.66 & 79.62 & 80.32 & $1.48 \pm 0.13^{b}$ \\
\hline SCB 7.5 & 0.02 & 12.57 & 51.79 & 61.16 & 65.37 & 67.03 & 68.03 & 68.81 & $1.84 \pm 0.19^{c}$ \\
\hline SCB 10.0 & 0.02 & 9.95 & 47.52 & 58.21 & 62.90 & 64.79 & 65.92 & 66.80 & $2.37 \pm 0.14^{\mathrm{d}}$ \\
\hline
\end{tabular}

*Mean \pm SD

Different superscript letters in the same column indicate significant difference by Duncan's multiple range test $(\mathrm{p}<0.05)$.

SCB: Sugarcane bagasse 


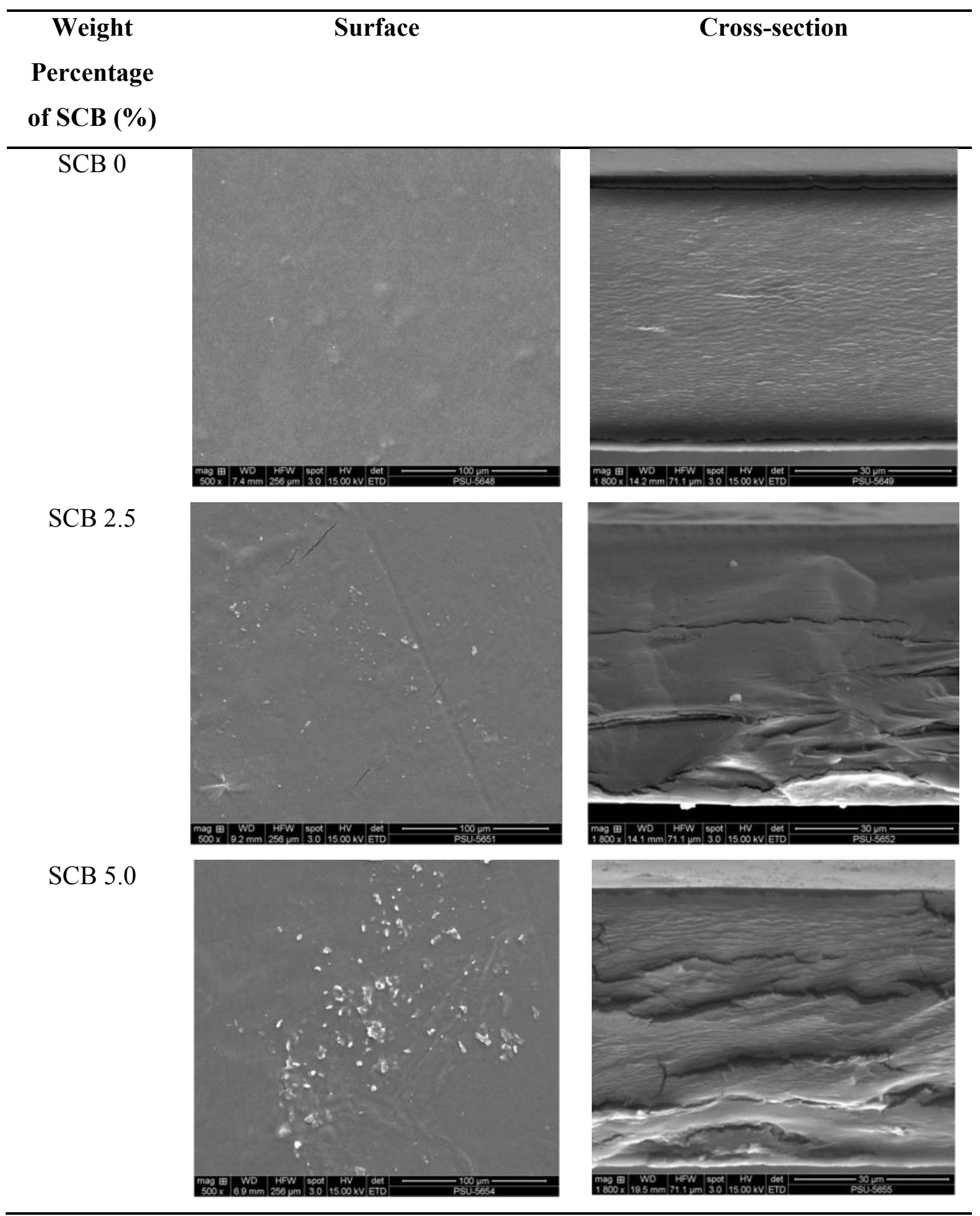

(c) Emerald Group Publishing Limited

This is a pre-print of a paper and is subject to change before publication. This pre-print is made available with the understanding that it will not be reproduced or stored in a retrieval system without the permission of Emerald Group Publishing Limited. 


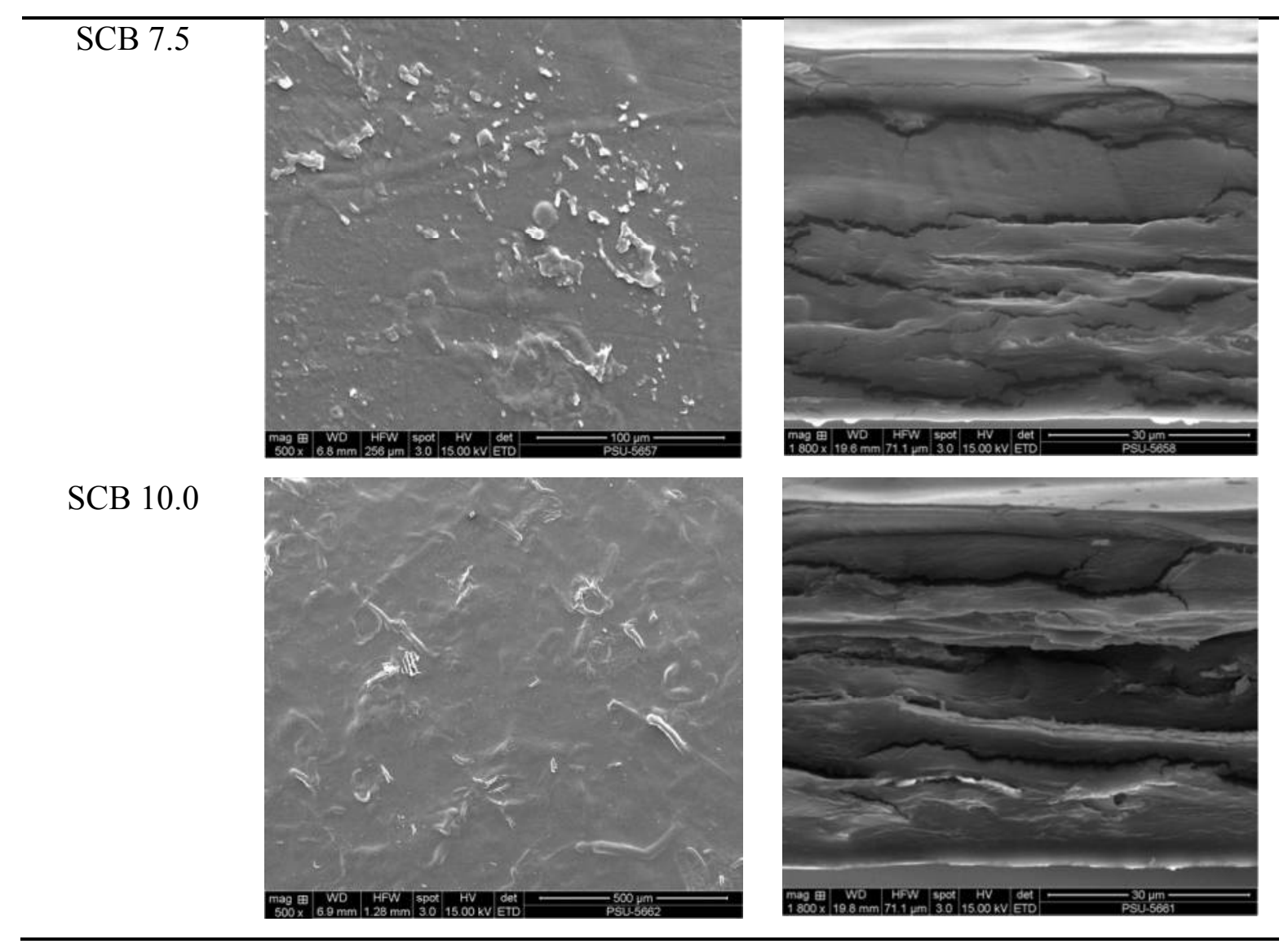

SCB: Sugarcane bagasse

Figure 1. Scanning Electron Microscopy micrographs of surface (magnification: 500x) and cross section (magnification: 1800x) of films from chicken feet gelatine incorporated with different levels of weight percentage of SCB. The SCB 0 which is the control film showed smooth and homogeneous surface. The cross-section of the control film also showed smooth surface. As the weight percentage of hydrolyzed SCB increases, the surface of the films showed increment in white spots. The white spots are believed to be the hydrolyzed SCB. 